\title{
"Core-Periphery" in the European Union - An Economic Perspective
}

\author{
Ines Kersan-Škabićn ${ }^{*}$ \\ 1 Faculty of Economics and Tourism “Dr. Mijo Mirković”, Juraj Dobrila University of Pula, Ul. Petra Preradovićeva 1/1, 52100, \\ Pula, Croatia \\ * Corresponding author, e-mail: ikersan@unipu.hr
}

Received: 04 March 2019, Accepted: 12 November 2019, Published online: 15 April 2020

\begin{abstract}
The heterogeneity of economic performances in the EU member states is one of the main reasons for the existence of a "core-periphery" relationship. The goal of this research is to examine various economic indicators to reveal possible divisions between the EU members. This issue emphasized the contribution of rich "core" countries to the imbalances in poorer "peripheral" EU members. By applying cluster methodology and considering the most recent data, two groups of countries were identified, the first comprising 11 countries that form the "centre" or the "core", and the rest of the EU forming the "periphery". Considering differences between these countries is necessary and justified for discussions about the future development of the EU that will involve differences between member states.
\end{abstract}

\section{Keywords}

core, periphery, EU, cluster analysis

\section{Introduction}

The European Commission (2017) has presented a White Paper on the future of Europe which outlines five different scenarios about the possible ways of cooperation between member states. Some of these scenarios allow for EU membership that is not of the same intensity for all members: some of the members could create a stronger union, and some of them could participate only in trade and investment issues of the possibility of an EU of this kind has raised the question of the "core-periphery model". Evidence of such a model also appeared during and after the global financial crisis (from 2008 onwards), but with a possible and uncertain new division in the EU, it will become even more obvious.

The concept of "core-periphery" can be analysed from various different perspectives: historical, economic, geographical (Vanolo, 2010) and political. The historical approach differentiates the "original six" (countries that signed the Paris and Rome treaties in 1951 and 1957 respectively) that established the first integrations in Europe ${ }^{1}$ and the enlargements of such integration completed by 1995 (the "core" countries or EU-15) from the countries that

1 European Coal and Steel Community (ECSC) and European Economic Community (EEC). joined the EU in the 2000s (new member states). From the economic point of view, the countries can be categorised as core or periphery according to their economic achievements (development, trade imbalances, fiscal indicators, etc.). In addition, there is Eurozone division into core and periphery states, where the periphery can be both inner (Eurozone member states - South EU) and outer (non-Eurozone member states, but EU members). The same can be applied to the core which can also be inner and outer (Eurozone members and non-Eurozone core members). Bartlett and Prica (2016) additionally define super-periphery - countries of the Western Balkans (non-EU members). The political aspect includes the democracy gap between periphery and core, where new member states are lagging behind due to a long period of having one-party political systems, followed by a process of transition (at the beginning of the 1990s) with the gradual establishment of democracy and new institutions. Some of the new member states have reduced, formally legal, low-performing democracies with poor governance and non-sustainable social progress. Accordingly, the expectation that the collapse of communism and the victory of Western liberalism would make for swift convergence between the Eastern and Western parts of Europe has turned out to be an illusion. 
The goal of this paper is to analyse whether the division between "core-and-periphery" still exists in the EU, 10 years after the global financial crisis and in the context of a debate about the future of the EU. The analysis will cover all the 28 EU member states and groups of "core" and "periphery" areas will be based on various economic indicators such as: GDP p.c., current account (im) balances, fiscal indicators (budget deficit and public debt share in GDP) and the various rates of migration. The last variable seems to be very important due to the fact that participation in the Single Market opens the borders for migration of people between EU member states. The core countries, being more developed, are attractive destinations for the immigration of the working population from periphery countries that face a higher level of unemployment and lower wages. A country can thus be considered to belong to the periphery if it has negative migration balance (emigration is higher than immigration). A cluster analysis will be carried out for all the variables with the aim of determining which of these two groups a particular country belongs to. The novel aspect of this paper is that it aims to identify the different groups of EU member states considering different variables, as well as comparing the results of two clustering approaches.

\section{Literature review}

The easiest and first way of differentiating core from periphery countries is according to their geographical position, but today the concept of core-periphery has expanded to include different aspects and characteristics. In economics, a commonly used indicator is GDP per capita to divide countries into a group of highly developed (with above-average GDP per capita) EU members and other EU member states (with below-average GDP per capita). For the purpose of the EU cohesion policy, the NUTS2 regions are divided into three groups of regions: regions with GDP per capita below $75 \%$ of EU28's GDP per capita, regions with GDP per capita in the range from 75-90\% of EU28's GDP per capita and regions with a GDP per capita higher than $90 \%$ of the EU28's GDP per capita.

Core-periphery models also appear within national economies and describe the concentration of activities in urban areas vs. peripheral areas (regions), i.e. concentration-dispersion forces.

New Economic Geography (NEG) is the analytical framework established by Krugman in the early 1990s to explain the formation of various types of economic agglomerations in geographical space. Krugman (1991) uses a general equilibrium model and explains what, how and when the concentration of activities is affected and why there is a difference in spatial development. His explanations are applicable both to the agglomeration of activities at the urban and regional level, and at the country level (North-South division). This concept of a two-region core-periphery model has become the basis of the NEG that seeks to integrate urban, regional and international economics in a single theoretical framework and, more generally, to remedy the omission of space from mainstream economics.

Core-periphery models will appear where the core is developed (with the domination of industry) and the periphery is underdeveloped (where the agricultural sector is dominant). This very simple explanation should nowadays be complemented with more variables when attempting to define core and periphery. This concept can be applied to explain not only the concentration/dispersion of activities in one particular country, but also at the EU level to explain the similarities and differences between EU member states.

Some authors have proposed a relationship whereby the core developed EU centre contributes to the appearance and deepening of the imbalances in South and South-East Europe (Lapavitsas et al., 2010). Bartlett (2014) explains the core-periphery model in the EU in terms of the dependency between highly developed core countries and the countries of South-East Europe. He points out that the import demand and credit activities in South European countries contributed to current account surpluses in "core" countries that were faced with under-consumption and were threatened by stagnation. He suggests a better way out of the current period through coordinated fiscal expansion to stimulate domestic and Europe-wide demand. The developed EU member states should play a role in solving the problems of South-European countries because they influence their ability to sustain development perspectives. Nikolovska and Mamucevska (2015) confirm the thesis that the core countries with current account surpluses became richer thanks to their export to and investment in the EU periphery. Armingeon and Baccaro (2012) also found that the German current account surplus is equal to the deficit of Greece, Spain, Portugal and taly together, indicating that Germany and other "core" countries developed their economies thanks to their exports to South-European countries. The authors also found that the internal devaluation policy is inadequate in the EU peripheral countries. Steinberg and de Cienfuegos (2012) indicate the political and economic risks associated with 
the German strategy to solve the Eurozone's debt crisis. They warn that Germany is leading the reform of the Eurozone's governance, but it is doing so based on an incomplete diagnosis of the crisis, believing that fiscal austerity will be enough to save the euro. They argue that the German strategy of "authoritarian austerity" is hindering economic growth in Europe. The division between Eurozone members with current account (CA) surpluses and Eurozone members with CA deficits is called "Eurozone CA core-periphery dualism" and it is a product of both the long-run sustainability of peripheral EU member states' finances and the ineffectiveness of centralised interventions within the euro area.

The asymmetry of power between core and periphery in EU has made it very difficult for the peripheral states to obtain sufficient political capacity to secure an alternative policy mix. Caraveli (2012) analysed a set of macroeconomic variables across EU regions, and found that although the core-periphery is still persistent, EU regional policy has had a positive impact on the reduction of regional inequalities.

Sobják (2013) pointed out the increasing differences even between Central and Eastern European countries (EU member states) which formed a more homogeneous group before the crisis, and discussed the divide between EU member states in the post-crisis period. The crisis has also affected the economic geography of the EU because some new member states have achieved better performance than some of the Southern members of the EU15 and this could be a way of improving their position in the EU.

Bayoumi and Eichengreen (1993) raised concerns about a core-periphery divide of the EU even in the period of pre-EMU. They estimated the degree of business cycle synchronisation, and argued that there is a core of EU states (Germany, France, Belgium, Netherlands, and Denmark) where supply shocks are highly correlated, and a periphery (Greece, Ireland, Italy, Portugal, Spain, and the UK) where synchronisation is significantly lower. Campos and Macchiarelli (2016) used the same methodology and found that the core-periphery pattern has weakened over the last 25 years. Moreover, Pentecôte and Huchet-Bourdon (2012) extended the Bayomi and Eichengreen (1993) study. They applied Euclidean distance to the core, and found that shock asymmetry mostly arose from the production or the demand side. They analysed the period from 1996 to 2008 in 21 countries and found evidence of a gradual move to the symmetric core while new EMU Member States remained at the very periphery. De Santis and Cesaroni (2016) found that financial integration played a role in explaining CA dynamics in the EU countries and had a negative impact on the Eurozone periphery (in the post-Euro period). Botta (2012) warns of conflicting interests in the Eurozone, emphasizing that diverging trends have arisen in the post-crisis period in the Eurozone periphery and the conflicting claims of euro countries may represent decisive obstacles to the reform of the Eurozone into a complete federal entity. "However, they may prove to be self-defeating in the long run should financial turbulences seriously deepen in the large peripheral countries" (Botta, 2012:p.1).

Kottaridi (2005) studied the implications of foreign direct investments for the core-periphery division in the EU. She found a differentiation between these groups of countries where FDI and human capital had a significant role in the core countries, while in peripheral areas, in most cases, these variables turned out to be incapable of boosting growth. The author explained these results with reference to the host characteristics of the regions: the technology-based attractiveness of the core vs. a duality of market and the cost advantages of the periphery.

Neck and Blueschke (2014) analysed the asymmetry in the EU (Eurozone) regarding the level of public debt. The core countries have lower initial public debt while the periphery countries have higher levels of initial public debt. They concluded that the "periphery" may experience a "haircut" due to the high level of its sovereign debt, but this kind of "haircut" as modelled in their study is disadvantageous for both the "core" and the "periphery" of the monetary union.

Wortmann and Stahl (2016) applied different cluster algorithms to a set of Macroeconomic Imbalance Procedure indicators and found that both the core Eurozone countries and the United Kingdom, Denmark, and Sweden are suited to having a common currency, while the other group of countries (Greece, Ireland, Italy, Portugal, and Spain plus Cyprus and Croatia) on the southern periphery, as well as most of the countries of the eastern enlargement, are found to form very distinct clusters in terms of competitiveness, indebtedness, and economic performance.

Lehwald (2013) found that the main macroeconomic variables move in the same direction for the core Eurozone countries from the pre-euro period to the euro period, while they decrease for the most peripheral economies. There is an evidence of increases in business cycle synchronization for the core and a decline for the periphery. The introduction of the euro has fostered imbalances between core and peripheral Eurozone countries.

There is even a core-periphery tendency in science and innovation policy, where the periphery countries 
achieved some level of convergence with the core in the pre-crisis period, but this model can be recognized only on the practical level of governance and policy-making (Lažnjak and Švarc, 2016).

Thomas (2013) discusses the core-periphery model in the context of regional policy and by comparing some economic indicators draws conclusions about the concentration of industrial activities in core countries of the EU.

Pascariu and Ţigănaşu (2017) point to the existence of the core-periphery division in the EU due to enlargement and implement a composite index of peripherality to find out the determinants of convergence and growth in Central and Eastern Europe and to assess the effectiveness of regional policy in the EU. They discuss Eastern and Southern peripherality and distinguish two types of peripherality: economic and spatial. They propose developing an integrated approach reflecting the complexity of the economic and spatial processes which affect the European economy and propose a composite index. The index of economic peripherality includes GVA (Gross value added) per employee, trade openness (export and import share in GDP), and inward FDI stocks in GDP. They concluded that "free trade/transactions on the common market may emphasize the gaps through processes of industrial agglomeration, at least at regional and intra-national levels; FDI produces positive effects on competitiveness, but is more volatile during crises (bearing the risk of amplifying asymmetric shocks) and its effects on GVA are lower than on local capital..." (Pascariu and Jigănaşu, 2017:p.71).

Caraveli (2017), provides graphical presentations of the main trends in Central and Eastern Europe and in South Europe and underlines the necessity of including labour productivity and FDI inflows as indicators to make a distinction between Southern peripherality and Central and Eastern European peripherality. She describes the coreperiphery model in Europe thus: "the EU core still covers the area between London, Paris, Milan, Munich and Hamburg. It has been subject to transformations over the years:

- around the 1990s, new centres appeared in Southern Europe, forming a 'southern development zone' extending from North-Eastern Spain to Northern Italy;

- new centres have emerged in the past 10 years in capitals such as Warsaw, Prague, Bratislava, Budapest and Bucharest" (Caraveli, 2017:p.18).
The core-periphery pattern in Europe exists and expresses a fragile equilibrium which reflects the dynamics of change. In addition, she points out that "the core-periphery gap remains quite strong in terms of competitiveness and productivity levels, weakening the EU's competitive position globally vis-a'-vis other large economies..."(Caraveli, 2017:p.18).

Da Silva (2017) also researched the Central- Eastern peripherality vs. Southwestern peripherality in the EU. Besides the previously mentioned indicators she introduced the export structure in the analysis of convergence and found out that Eastern European countries have shown greater capabilities of catching-up (until 2008) and of stimulating export-led growth. That is related to a strong manufacturing sector and compatible with the increase of technology readiness and skill-intensive activities. Nevertheless, after the crisis both groups of countries have been unable to catch up with the EU core.

Caporale et al. (2014) focused their research on the cases of Romania and Bulgaria and their catching up with the rest of the EU. Specifically they wanted to find out whether there is a shift towards intra-industry trade leading to economic convergence and technological catch-up. They found that the "results indicate that intra-industry trade has indeed increased, but it is of the vertical rather than horizontal type, resulting in complementary rather than competitive production patterns" (Caporale et al., 2014:p.1).

\section{Research}

\subsection{Data and methodology}

Based on the literature reviewed above, it is clear that countries can be compared and divided into the "core" and "periphery" in terms of various variables: GDP p.c., public debt $(\%$ of GDP), trade surplus/deficit (Caraveli, 2017); investment in R\&D, FDI (Kottaridi, 2005); macroeconomic imbalance procedure (MIP) indicators (Wortmann and Stahl, 2016), CA (Armingeon and Baccaro, 2012) and fiscal variables (Neck and Blueschke, 2014).

We decided to include the following variables in our analysis: GDP per capita in euro (constant prices), GDP growth rate $(\%)$, public debt ( $\%$ in GDP), budget deficit $(\%$ in GDP), CA surplus/deficit (\% in GDP), trade openness (export of goods and services/GDP or import of goods and services/GDP), trade surplus/deficit (\% in GDP), intra-export and intra-import (in \% of total export or import), migration flows (crude rate of migration on 1,000 inhabitants), 
inward FDI (\% in GDP) chosen MIP variables: international investment position (IIP) ${ }^{2}$, unit labour costs (ULC, the ratio of labour costs to labour productivity), unemployment rates (\%). The data are from the Eurostat database and refer to 2017, or the three-year-period average (for MIP indicators). The analysis is made applying Stata 14.

To connect responses given by similar countries, we conducted a cluster analysis (Hair et al., 2010).

Multivariate cluster analysis is one of the methods which group objects into small homogeneous groups (clusters) which are heterogeneous with each other. At the beginning of clustering it is important to decide whether we know in advance how many clusters should be generated by the analysis or whether we will accept the final number of clusters that will be produced by cluster analysis. By applying different clustering algorithms, different results on the same data can be obtained. Various clustering methods can be applied: linkage methods (single linkage method, complete linkage method, average linkage method), Ward's method, and the centroid method. They differ regarding the method of calculating the distance between clusters. The idea is to create groups that are very homogeneous. The most common approaches are either hierarchical or non-hierarchical. The first - hierarchical clustering - is depicted by a tree or dendrogram. There are two approaches to hierarchical clustering: we can go "from the bottom up", grouping small clusters into larger ones, or "from the top down", splitting big clusters into small ones. These are called agglomerative and divisive clustering, respectively. The basic algorithm is very simple: start with each point in a cluster of its own until there is only one cluster; find the closest pair of clusters, merge them, then return to the tree of cluster-mergers.

We applied two methods:

- a hierarchical cluster analysis (Ward's methodology) and

- $k$-means methodology.

Ward suggested a general agglomerative hierarchical procedure, where the criterion for choosing the pair of clusters to merge at each step is based on the optimal value of an objective function. Ward's method starts with $n$ clusters, each containing a single object. These $n$ clusters are combined to make one cluster containing all objects.

2 The difference between an economy's external financial assets and liabilities is the economy's net IIP, which may be positive or negative. The MIP scoreboard indicator is the net international investment position expressed in percent of GDP.
At each step, the process forms a new cluster that minimizes variance, measured by an index called $E$ (the sum of squares index) Ward's minimum variance criterion minimizes the total within-cluster variance. To implement this method, at each step it is necessary to find the pair of clusters that leads to the minimum increase in total within-cluster variance after merging. This increase is a weighted squared distance between cluster centers. The initial distance between individual objects must be (proportional to) squared Euclidean distance (L2). We used Euclidean metric but were confronted with a dilemma as to whether to apply the complete linkage method or Ward's method. The complete linkage method calculates the differences between the two most distant units, whereas Ward's method computes the sum of the squared distances within the clusters. It aggregates clusters with the minimum increase in the overall sum of squares. All variables were standardized (z-scores) before clustering because of the different scales used. The number of clusters should not be known in advance, as the appropriate number will be found through the analysis. This is the main benefit of using this method. The idea is to find groups of units that share the same characteristics (very small differences among units in a group) and significant differences (variation) between the clusters (Stata, 2019).

The second method is k-means with the predefined two clusters. K-means is a prototype-based, partitional clustering technique, because it gives only a single set of clusters, with no particular organization or structure within. It attempts to find a user-specified number of clusters (K), which are represented by their centroids. K-means defines a prototype in terms of a centroid, which is usually the mean of a group of points, and is typically applied to objects in a continuous n-dimensional space. However it could easily be the case that some clusters could, themselves, be closely related to other clusters, and more distantly related to others. In centroid-based clustering, clusters are represented by a central vector, which may not necessarily be a member of the data set. When the number of clusters is fixed to $k$, k-means clustering gives a formal definition as an optimization problem: find the $k$ cluster centers and assign the objects to the nearest cluster center, such that the squared distances from the cluster are minimized (Stata, 2019).

\subsection{Results}

On the basis of the variables detailed above and applying the Ward's method several dendrograms were generated. The first dendrogram shows the grouping of EU members 
by only one variable: GDP per capita. A hierarchical formation of clusters is present, in which comprises two groups of countries. The first group includes Belgium, Germany, Finland, Austria, France, UK, Denmark, The Netherlands, Sweden, Ireland and Luxembourg and the second group includes Bulgaria, Romania, Croatia, Latvia, Hungary, Poland, Lithuania, Czech Republic, Greece, Portugal, Estonia, Slovakia, Malta, Slovenia, Spain, Cyprus and Italy. The first group represents the richest part of the EU, the "core", while the second group of countries have a significantly lower level of GDP per capita. The second group of countries includes all of the new EU member states, as well as Spain, Greece, Portugal and Italy from the EU-15 (see in Fig. 1) ${ }^{3}$.

Fig. 2 shows the clustering of EU member states according to Macroeconomic Imbalance Indicators. This clustering drew on several indicators: current account deficit, net international investment position, unit labour costs, public debt, unemployment rates, youth unemployment rates. In Fig. 2 it is worth noting that after hierarchical grouping, three clusters were evident. the first of which is composed of Belgium, Denmark, Luxembourg, Germany, Malta, The Netherlands; the third comprising only Ireland, Spain, Cyprus, Portugal and Greece while the second cluster contains the rest of the states of the EU. According to the MIP indicators selected cluster 3 consists of the so-called PIGS or GIPS countries that were most affected by the consequences of the global economic crisis and which were compelled to request financial aid from the International Monetary Fund and the EU. In the final stage, clusters 1 and 2 form one cluster and cluster 3 forms the second group.

In Fig. 3, if Malta is excluded, the EU members form two clusters based on migration characteristics. The first cluster consists of Belgium, Ireland, The Netherlands, Austria, Germany, Denmark, Estonia, Spain, Cyprus, Sweden and Luxembourg while the second cluster is made up of the rest of the EU states.

3 The numbers in the horizontal axis of the figures represents the countries which were the subject of this study:

1 = Belgium; 2 = Bulgaria; 3 = Czech Republic; 4 = Denmark;

$5=$ Germany; $6=$ Estonia; $7=$ Ireland; $8=$ Greece; $9=$ Spain;

$10=$ France $; 1=$ Croatia; $12=$ Italy; $13=$ Cyprus; $14=$ Latvia

$15=$ Lithuania; $16=$ Luxembourg; $17=$ Hungary; $18=$ Malta;

$19=$ Netherlands; $20=$ Austria; $21=$ Poland; $22=$ Portugal

$23=$ Romania $; 24=$ Slovenia; $25=$ Slovakia $; 26=$ Finland;

$27=$ Sweden; $28=$ United Kingdom

L2 squared= Euclidean distance

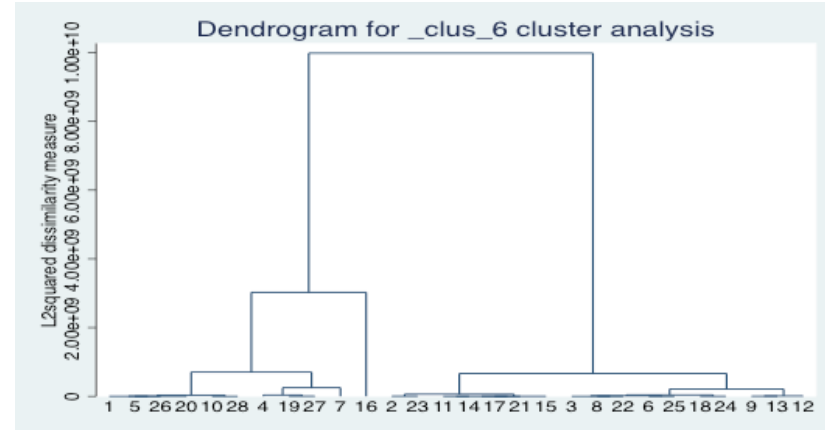

Fig. 1 Dendrogram of EU 28 based on GDP per capita

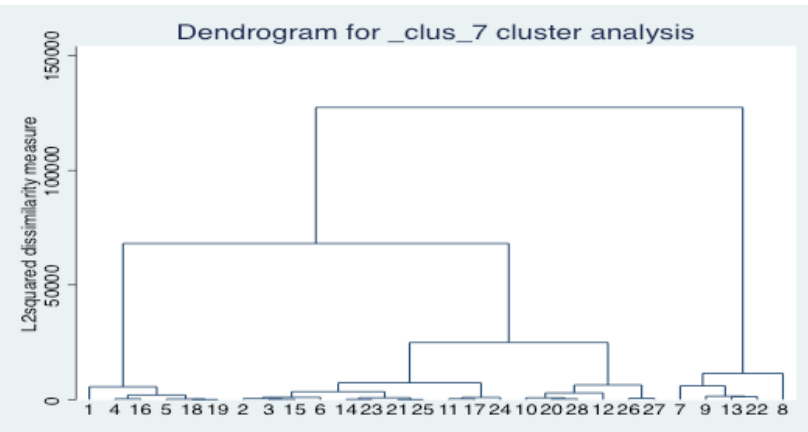

Fig. 2 Dendrogram of EU 28 based on MIP indicators

It is worth noting how to determine which of these two groups a particular country belongs to. Italy, Finland and France belong to the second group of countries with respect to migration (which includes the new EU member states, Portugal and Greece). The reason is that for these countries the crude rate of migration per 1,000 inhabitants is negative (Italy -7.7) or has positive, but very small values (i.e. France 1; Finland 0.7$)^{4}$. Thus these countries may be experiencing negative natural population growth rates which do not solely stem from emigration. This is the difference between these countries and the new EU member states which are witnessing both negative trends: higher levels of emigration compared to immigration (a tendency which EU membership contributed to) as well as negative natural population growth (see in Fig. 4).

Based on public debt data, the EU can be divided into two clusters. The following countries belong to the first grouping: Belgium, Spain, France, Cyprus, UK, Italy, Portugal and Greece. These countries have a high level of public debt while other countries form the second cluster. In the first group, the UK has the lowest level of public debt $(87.4 \%$ of GDP), while Greece faced the highest level

4 This indicator is equal to the difference between the crude rate of increase and the crude rate of natural increase (that is, net migration is considered as the part of population change not attributable to births and deaths). 


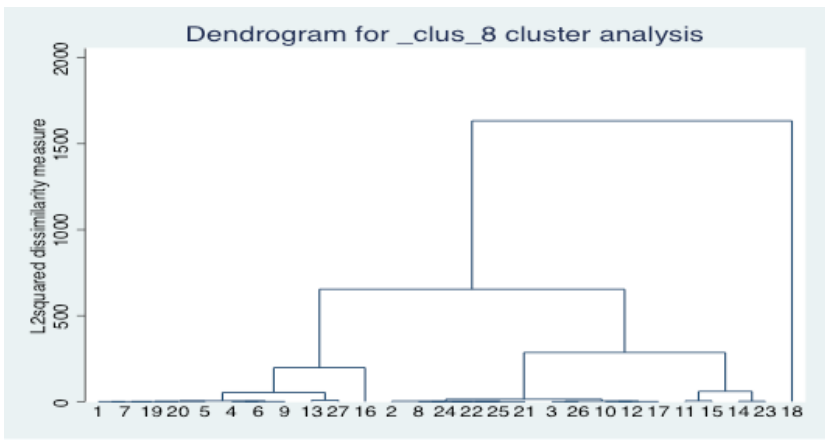

Fig. 3 Dendrogram of the EU28 based on migration flows

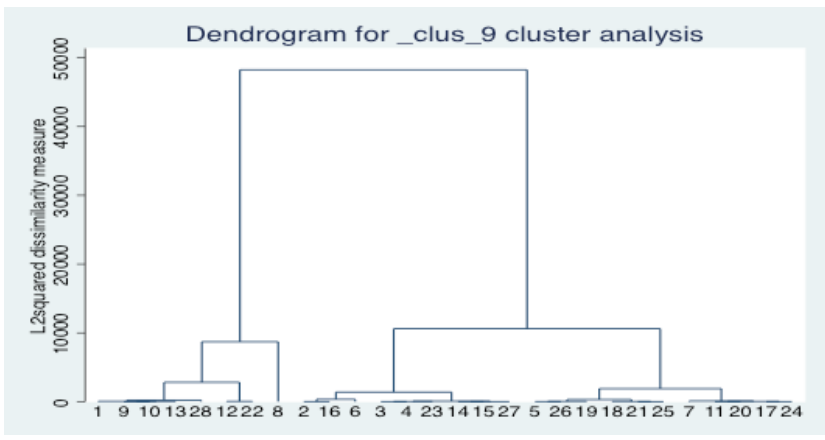

Fig. 4 Dendrogram of the EU28 based on public debt and budget deficit

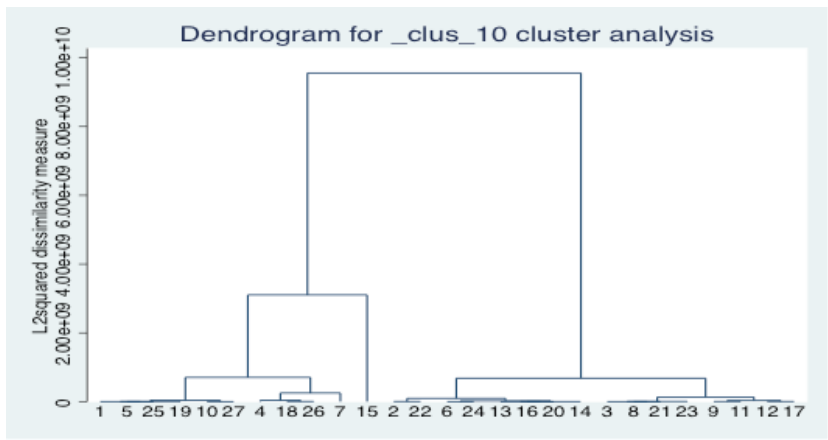

Fig. 5 Dendrogram of the EU28 based on all variables

(176 \% of GDP). In the second group, Estonia has the lowest rate of public debt-to-GDP (just $8.7 \%$ ) while Austria has the highest level ( $78 \%$ of GDP).

According to Fig. 5, which covers all the above data, a clear distinction is evident between two clusters of EU member states. The first grouping comprises Belgium, Germany, Slovakia, The Netherlands, France, Sweden, Denmark, Malta, Finland, Ireland and Lithuania while the rest of the EU belong to the second cluster. The interesting point here is that three new EU member states belong to cluster one.

We also applied the k-means method by defining the two clusters and including all the variables mentioned above. According to this method, the following eleven countries belong to the first cluster: Belgium, Denmark,
Germany, Finland, France, Ireland, Luxembourg, Netherlands, Austria, Sweden, and the UK. The rest of the EU forms the second cluster.

\subsection{Discussion}

The analysis produced several common findings. Even the new EU member states have made progress through higher growth rates than the EU-15, although convergence is still far away and below the expected level. The results of the analysis suggest that the periphery of the EU does not only include the new EU member states, but also some southern members of the EU-15. The weakness of these latter countries emerged during and after the global economic crisis when, with the deterioration in the external market, the flaws in their internal economic policies resulted in increased indebtedness, high unemployment rates, emigration and stagnation. The problems revolved around how to change the patterns of economic policies that were based on huge consumption and import. It is necessary to consider the structure of the economy (of production, resources, export and import) of each country when proposing the measures/policies they should implement to solve the imbalances they faced. There is no copypaste model and no unique, clear-cut solution. If they are to be satisfied with their membership of the EU, it is highly likely that some countries will not wish to participate in the deepening of the EU if they do not see the benefits for their economies and if they predict that it will lead to further risks and uncertainties. The discussion about the scenarios of the future of the EU will reveal both the interests of particular countries and of the political groups in the EU Parliament and will indicate the direction in which the EU should be built in the future.

\section{Conclusion}

The analysis in this paper appears to confirm that a core-periphery problem exists in the EU. Based on various economic indicators, the results show that the core is formed by Belgium, Denmark, Germany, Finland, France, Ireland, Luxembourg, The Netherlands, Austria, Sweden, and $\mathrm{UK}^{5}$. The periphery consists of Bulgaria, Czech Republic, Estonia, Greece, Spain, Croatia, Cyprus, Latvia, Lithuania, Hungary, Malta, Poland, Portugal,

5 Even though Brexit is scheduled for the end of March 2019 (with two delays), the United Kingdom was here considered as an EU member to show that according to its economic characteristics, it belongs to the EU core (EU center). 
Romania, Slovenia and Slovakia. These findings support the thesis of heterogeneity in the EU, which implies different interests, different needs and expectations across the members of the EU common market, of the Euro area and of the EU institutions. The core countries (except the UK due to Brexit) can consider further deepening of the EU if they are able to reach a consensus between the political parties in their countries and if the federal idea of integration overcomes the right wing political orientation which currently emphasizes higher protection of national interests and which has a growing power.

The periphery countries also, unquestionably, benefit from participation in the EU single market and from the EU policies (e.g. the cohesion policy through European Structural and Investment Funds or the agricultural policy), but due to their characteristics it would be very ambitious if they wanted to see the EU development in the same direction and to the same extent as in the EU core. It is necessary to consider their characteristics, economic development path, economic structure and their specific features when preparing for the EU of the future. They belong to the EU and want to be a part of it, but they

\section{References}

Armingeon, K., Baccaro, L. (2012) "Political Economy of the Sovereign Debt Crisis: The Limits of Internal Devaluation", Industrial Law Journal, 41(3), pp. 254-275. https://doi.org/10.1093/indlaw/dws029

Bartlett, W. (2014) "Interdependence between Core and Peripheries of the European Economy: Secular Stagnation and Growth in South East Europe", Paper presented at Economic Growth: Stimuli and Constraints, Aksakovo, Sofia, Bulgaria, October 6-7 2014.

Bartlett, W., Prica, I. (2016) "Interdependence between Core and Peripheries of the European Economy: Secular Stagnation and Growth in the Western Balkans", The London School of Economics and Political Science (LSE), London, UK, Discussion Paper No. LEQS Paper No. 104.

https://doi.org/10.2139/ssrn.2729882

Bayoumi, T, Eichengreen, B. (1993) "Shocking aspects of European monetary integration", In: Torres, F., Giavazzi F. (eds.), Adjustment and Growth in the European Monetary Union, Cambridge University Press, Cambridge, UK, pp. 193-235. https://doi.org/10.1017/CBO9780511599231.014

Botta, A. (2012) "Conflicting Claims in the Eurozone? Austerity's Myopic Logic and the Need for a European Federal Union in a Post-Keynesian Eurozone Center-Periphery Model", The Levy Economics Institute Working Paper, No. 740. https://doi.org/10.2139/ssrn.2187410

Campos, N. F., Macchiarelli, C. (2016) "Core and Periphery in the European Monetary Union: Bayoumi and Eichengreen 25 years later", Economic Letters, 147, pp. 127-130. https://doi.org/10.1016/j.econlet.2016.07.040 also want to achieve better economic performance and wellbeing for their population. The needs, ideas and vision of the core and the periphery countries will probably not be the same, but they will move in the same direction, because they recognize the benefits of the EU membership. Given this heterogeneity, it is all the more important to reach agreement over the way that the EU will function in future and reach acceptable compromises on important and divisive issues such as migration and the EU budget after 2020 in order ensure the continued and beneficial coexistence of all EU members.

\section{Acknowledgments}

This paper is a result of scientific project "The determinants and challenges of competitiveness" supported by the Faculty of Economics and Tourism "Dr. Mijo Mirković", Juraj Dobrila University of Pula. Any opinions, findings, and conclusions or recommendations expressed in this paper are those of the author(s) and do not necessarily reflect the views of the Faculty of Economics and Tourism "Dr. Mijo Mirković" Pula.

Caporale, G. M., Rault, C., Sova, R., Sova, A. (2014) "International trade and economic catch-up", [online] Available at: https://pdfs.semanticscholar.org/5c7e/cbe04f8e7cd887673a04470b95306c8c01cb.pdf [Accessed: 15 October 2018]

Caraveli, H. (2012) "The EU core-periphery divide in the new regional and global setting: a Reflection of the New Economic Geography Paradigm?", IJABER, 10(2), pp. 233-254.

Caraveli, H. (2017) "The Dynamics of the EU Core-Periphery Division: Eastern vs. Southern Periphery - A Comparative Analysis from a New Economic Geography Perspective", In: Pascariu, G ., Duarte, M. (eds) Core-Periphery Patterns Across the European Union, Emerald Publishing Limited, Bingley, UK, pp. 3-22. https://doi.org/10.1108/978-1-78714-495-820171001

da Silva, E. G. (2017) "EU Integration and the Centre Periphery Divide: Growth and Structural Change in Southern and Eastern European Countries", In: Pascaru, G., Duarte, M. (eds) Core-Periphery Patterns Across the European Union Emerald Publishing Limited, Bingley, UK, pp. 89-112.

https://doi.org/10.1108/978-1-78714-495-820171003

De Santis, R., Cesaroni, T. (2016) "Current Account 'Core-Periphery Dualism' in the EMU", The World Economy, 39(10), pp. 1514-1538. https://doi.org/10.1111/twec.12418

European Commission (2017) "NA-01-17-150-EN-1 White Paper on the future of Europe, Reflections and Scenarios for the EU27 by 2025", Brussels, Belgium. https://doi.org/10.2775/32364

Hair, J. F., Black, W. C., Babin, B. J., Anderson, R. E. (2010) "Multivariate Data Analysis", Upper Saddle River, Pearson, London, UK. 
Kottaridi, C. (2005) "The 'core-periphery' pattern of FDI-led growth and production structure in the EU", Applied Economics, 37(1), pp. 99-113.

https://doi.org/10.1080/0003684042000291308

Krugman, P. R. (1991) "Increasing Returns and Economic Geography", Journal of Political Economy, 99(3), pp. 483-499. https://doi.org/10.1086/261763

Lažnjak, J., Švarc, J. (2016) "Policy-making on science in society between Europeanization and core-periphery divide", Innovation: The European Journal of Social Science Research, 29(1), pp. 98-112. https://doi.org/10.1080/13511610.2015.1127138

Lapavitsas, C., Kaltenbrunner, A., Lindo, D., Michell, J., Painceira, J. P., Pires, E., Powell, J., Stenfors, A., Teles, N. (2010) "Eurozone crisis: beggar thyself and thy neighbour", Journal of Balkan and Near Eastern Studies, 12(4), pp. 321-373. https://doi.org/10.1080/19448953.2010.510012

Lehwald, S. (2013) "Has the Euro changed business cycle synchronization? Evidence from the core and the periphery", Empirica, 40(4), pp. 655-684.

https://doi.org/10.1007/s10663-012-9205-8

Neck, R., Blueschke, D. (2014) " "Haircuts" for the EMU periphery: virtue or vice?", Empirica, 41(2), pp. 153-175. https://doi.org/10.1007/s10663-014-9252-4

Nikolovska, N., Mamucevska, D. (2015) "Current Crisis in the EU in the Light of the Contradictions of the Core - Periphery Development Model", Review of Innovation and Competitiveness, 1(1), pp. 45-62. https://doi.org/10.32728/ric.2015.11/3

Pascariu, G. C., Ţigănaşu, R. (2017) "Integration, Growth and CorePeriphery Pattern in EU's Economy: Theoretical Framework and Empirical Evidences", In: Pascaru, G. C., Duarte, M. (eds) Core-Periphery Patterns Across the European Union, Emerald Publishing Limited, Bingley, UK, pp. 23-85. https://doi.org/10.1108/978-1-78714-495-820171002
Pentecôte, J S., Huchet-Bourdon, M. (2012) "Revisiting the core-periphery view of EMU", Economic Modelling, 29(6), pp. 2382-2391. https://doi.org/10.1016/j.econmod.2012.06.036

Sobják, A. (2013) "From the Periphery to the Core? Central Europe and the Economic Crisis", The Polish Institute of International Affairs, Policy Paper No. No.7/55.

Steinberg, F., de Cienfuegos, I. M. A. (2012) "The New Government Of The Euro Zone: German Ideas, Divergent Interests and Common Institutions", Revista De Economía Mundial, 30, pp. 59-81. [online] Available at: http://www.sem-wes.org/sites/default/files/ revistas/REM30_2_0.pdf [Accessed: 15 November 2018]

Stata (2019) "Cluster analysis", [online] Available at: https://www.stata. com/features/cluster-analysis/ [Accessed: 20 March 2019]

Thomas, B. C. (2013) "Core-Periphery Relations in the European Union and the Role of Central Places in Europe with a Focus on Regional Policy in Britain and Germany", European Review, 21(3), pp. 435-447. https://doi.org/10.1017/S1062798713000392

Vanolo, A. (2010) "The Border Between Core and Periphery: Geographical Representations of the World System", Tijdschrift voor Economische en Sociale Geografie, 101(1), pp. 26-36. https://oi.org/10.1111/j.1467-9663.2009.00508.x

Wortmann, M., Stahl, M. (2016) "One Size Fits Some: A Reassessment of EMU's Core-periphery Framework", Journal of Economic Integration, 31(2), pp. 377-413.

https://doi.org/10.11130/jei.2016.31.2.377 